DOI: 10.36108/ujees/0202.20.0120

\title{
Assessment of Retention on Valuation in the Nigerian Construction Industry - Clients' Perspective
}

Morakinyo, A. and Osuizugbo, I.C.

\begin{abstract}
The largest clients of Construction Industry (CI) in developing countries around the world are their respective governments. However, the CI in this clime is dominated by small and medium sized construction firms (SMSCFs). The aim of this study was to assess retention on valuation in the industry from the clients' perspective, with a view to improving financial performance of SMSCFs. Survey and non-probabilistic convenience sampling technique were adopted and data were obtained from industry stakeholders operating in Lagos. A total of fifty questionnaires validly completed were analysed using SPSS (Statistical Programme for Social Sciences) software Forty-four percent of the respondents have work experience in companies whose approximate annual turnover was $\leq$ N $100 \mathrm{~m} \leq$ N 500m. Finding shows that release of retention suffered from delay to outright non-payment of the retention monies and the retention practice of the three tiers of government is non-discriminatory of category of contractors. In conclusion, either delay or outright non-payment of retention monies on valuation will add to financial difficulty of SMSCFs Also, the retention policy of government, applying five (5) percent flat on their project does not consider the financial capacity of SMSCFs and latter's potential to contribute and grow the gross domestic product.
\end{abstract}

Keywords: Assessment, Retention, Construction industry, Nigeria, Clients' perspective

\section{Introduction}

Construction Industry's clients have a major contractual obligation to the contractor(s), for the work satisfactorily carried out by latter, that is, payment(s). Payments for construction contractual work are in different dimensions, which are collectively referred to as retention on valuations.

There can be, in the order of inflow (cash) of payment to the contractor: advance payment/ or mobilisation fee, interim payment, penultimate payment, final account payment and retention payment $[1,2]$.

\footnotetext{
Morakinyo , A. (Department of Quantity Surveying, Bells University of Technology, Ota, Nigeria)

Osuizugbo, I. C (Department of Building, Bells University of Technology, Ota, Nigeria)

Corresponding author:a morakinyo@bellsuniversity.edu.ng

Phone no +23408067888679
}

Retention amount refers to a sum of money held back from contractor in construction contract from progress payment [3, 4]. Also, retention is defined by [5] as 'a percentage of the value of a construction contract which is held by the client as an assurance of project completion and as a safeguard against defects which may come to light and which the contractor may fail to remedy'.

Retaining certain percentage of each progress payment to the contractors, by employer, is a common practice in CI which has lasted close to two centuries. This practice of retainage has inherent risks, such as overpayment for work installed, payment for defective work, and the continued solvency of the parties until the work is completed [3]. One of the events that resulted in the practice of retention was the large failure of contractors culminating into insolvencies, during the 
construction of the railway system in 1840 in the UK [3].

The UK construction industry's characteristics are largely replicated in most Commonwealth Nations - one of which is Nigeria. Nigeria CI is dominated by small and medium sized construction firms being a developing country [6]. Developing countries, like others, are expected to grow through contribution of industries to their gross domestic product (GDP). The GDP of Nigeria, for instance, is grown by $3.77 \%$ [7] during Q4 and full year, 2017; being the contribution of CI.

Although, the largest clients of Construction Industry (CI) are the governments of many developing countries in the world [8,9]. However, there are other clients, and they include: international organisation, religious organisations, manufacturing companies, financial services, general services and merchandise companies and property development companies [9-11]. It should be noted that both studies of [10] (effects of clients' type) and [9] (taxonomy of construction clients) are very import to the understanding of definitions, types and various classifications of clients in the CI. Clients refer to a person or firm responsible for commissioning and paying for the design and construction of a facility, [9] differentiate between paying client and users. In this study paying clients will be our focus.

Payment in construction contract is by stipulation. A breach of it can lead to the determination of the contract by the contractor.

However, hardly can delayed payment of release of retention monies lead to revocation of construction contract, thus, the payment practice is highly vulnerable to both insolvency and abuse [12]. According to [13] and [14], delayed payment affects the cash flow of the contractor, and tells more on Small and Medium sized Construction Companies (SMSCC) to a degree of closing down a business as aftermath of the problem. The fact that SMSCC is more exposed to payment problem is noted in the report of the Commonwealth Senate Committee on Economics [15].

According to that report on the security of payment in building and construction industry in Australia, construction market power is concentrated at the top of the contracting chain, with inequitably reallocating risk from the large contracting companies to those who are least able to bear it, namely subcontractors, suppliers and employees. Thus, any delay payment will tell more on SMSCC, because of their high probability of not being able to cope with it. Much more the release of retention does not attract interests. Since small and medium sized construction firms dominate CI in the developing countries, it will be very important to assess retention on valuation and how it affects financial performance of those companies from the relevant stakeholders such as clients, contractors and consultants in CI.

This paper focuses on clients' perspective on retention on valuation in construction industry in Nigeria. It examines the retention amount that is prevalent among different type and classification of clients in CI.

\section{Review of Literature}

Construction sector occupies important place in the economy of both developing and developed countries in the world $[16,6]$ and has a positive role to accelerate the economic growth of any country [17]. By 2020 
construction will account for $13.2 \%$ of the world GDP (the total dollar value of goods and services produced over a specific period) through the provision of basic infrastructure, such as road networks, commercial and residential buildings and facilities to other sector of economies [18].

Being an assemblage industry, there are small, medium, and large construction outfits operating in the industry which play an important part in the overall performance of construction industries across the whole world [19]. Irrespective of the construction company size, the players in the industry, who perform different role, include: the clients, contractors and consultants.

The client(s) conceive the investment idea and many a time seek construction experts' advice on feasibility and viability of a proposed undertaking. Following agreement between the clients and their advisers, contractors are called upon to carry out production on site. However, the procurement route just described is peculiar to traditional arrangement of carrying out construction works. There are other procurement routes such as design and build, turnkey arrangement and so on.

Although, as noted earlier, there are different sizes of construction companies [20], however, large volume of work is being undertaking by Small - Medium Construction Firms (SMCFs) [19]. , [19] presentation of analysis of structure of UK CI showed that SMCFs dominate the industry with the highest number $(99.8 \%)$ of construction companies and employed $74.2 \%$ of total construction workforce. As noted earlier, however, for SMCFs to serve as engine that drive activities in CI, the regularity of its cashflow is very important. Therefore, any interruption in payment streams to SMCFs will affect its performance. According to [14], delayed payment affects the cash-flow of the contractor, and tells more on small and medium sized construction companies to a degree of closing down a business as aftermath of the problem. One of the payments that are highly susceptible to delay is retention payment.

Retention amount refers to a sum of money held back from contractor in construction contract from progress payment [3, 4]. This held back amount will definitely be a burden to contracting firms who abni tio have financial challenges. [21] noted that with the low margins and high retentions associated with CI the contractor is automatically placed in a negative cash-flow position. In their study, [22] found that deduction of retention funds ranked highest among the factors that affect level of working capital requirements for home based contractor which in turn inhibits their participation in public sector construction projects.

Again, these financial challenges have been buttressed by Business Energy and Industrial Strategy (BEIS) [23] who noted that "some payment practices in the CI are a barrier to investment, productivity improvement and growth" Several authors have established that retention practice is a problem $[3,4,23,24$, $25,26,27]$. Having noticed that cash retention is a burden, the studies of [25] and [26] dwelt on alternative to cash retention and their benefits in Nigeria. Furthermore, the study of [28], in Ghana, showed that the level of retention can often be more than the level of profit margin, between $10-15 \%$, and that client, most often than not, deliberately or for other reasons best known to them, delay retention payment to contractors. 
In addition, the study of [29], indicated that delay payment by clients is one of the major problems faced by small scale construction contractors in India. Furthermore, the findings of [30] reiterated both lack of finance and delayed payment as important factors affecting the competencies and project delivery of small-sized indigenous construction firms in Lagos, Nigeria.

It should be noted, however, that there are different type of retention methods which construction clients can adopt. Some of these retention methods are: percentage, fixed amount, bank guarantee, insurance bond, joint bank account (a.k.a. project bank account) and credit letter $[26,31]$.

[26] found that the higher the initial cost of construction project, the higher the cost of retention bond. They also established that both neither the cost of securing nor time of processing retention bond result in cost and time overrun respectively. Also, in their study of management and administration of retention money on residential buildings, [31], discovered that deduction of $5 \%$ of project cost is prevalent among the respondents and as an alternative intervention system, payment of interest on delayed release of retention money is highly subscribed to by the respondents.

From the foregoing there is no contending the fact that client in CI, by the provision of the various contract forms, in most cases, except minor work, retain certain value of the work carried out by the contractor. Although, there is no one definition of client, a handy one provided by John Brandenburger, and quoted by Blackmore (1990) in [32], state that " clients are simply an assorted collection of men and women seeking advice from a member of one or more of the professions".
Another definition of clients is provided by British Property Federation (BPF, 1983) in [9], as "the person or firm responsible for commissioning and paying for the design and construction of facility". It should be noted, however, that there are different types of clients with different ability to influence activities in CI [10,33]. At this juncture, it is needed to be asked "do different clients in CI retain different or equal percentage of the value of work done by the contractors?" Previous studies on retention on valuation do not provide information to this inquiry. Therefore, it is important to know how much is being retained by different client because they influence activities in CI.

According to [10], construction client type is classified as follows; Government, Housing Authority, Other public sector clients, large developers, large industrial, commercial, and retailing organisations, medium and small industrial, commercial and retailing organisations; and other private sector clients.

Also, expanding classification of construction clients, [11], listed eleven types available in Nigeria, which are; Local government, State government, Federal government, International organisations, Club and association, Religious organisations, Individual, Manufacturing companies, Financial services companies, General services and merchandise; and Property development companies.

In addition, Newman et al (1981) in [32] produced a list of eighteen client types, such as: private commercial, industrial, developers, leisure, education, hospitals and public authorities among others. It should be noted that in the list of client drawn by [11], government parastatals was not brought out as separate client, compare with [10]. In any case, whichever type of client, it has been established that client delayed release of retention. However, it is not clear how much 
does different client retain for certified work for payment to be made to contractor.

\section{Research Methodology}

The aim of this study was to assess retention on valuations in Construction Industry (CI) from the clients' perspective, with a view to improving financial performance of SMSCFs. Survey research was adopted in this work. Survey, which is based on statistical sampling through questionnaires or interview, had been adjudged the most frequently used methods of data collection in exploration and evaluation research $[34,35,36]$.

The study was also ex post facto in design by the fact that the event being used in the construct had taken place. Data was obtained from building contractors and stakeholders operating in Lagos State. These contractors and stakeholders either had their operating offices in Lagos or they had on-going projects in the State. In construction projects, a percentage of payment for works they have done is withheld by clients according to agreed contract conditions. Consequently, information on retainage and its impact on project performance are better sourced or obtained from these participants. Thus, contractors and stakeholders such as Architects and Quantity Surveyors, among others, constitute the basic unit of analysis.

The non-probabilistic convenience sampling was adopted for this study. In probabilistic sampling, each of the elements (population of the contracting firms in Lagos State) have equal chance of been selected for sampling. The instrument for data collection was designed to obtain release of retention and possible impacts of retention on the project, duo which constitute project specific information and the experience on any one project executed or in which the respondent was involved in the last ten years (between 2009 and 2019).

Due to the unavailability of most qualified respondents to fill the questionnaires especially those administered to offices and on the web, most of the questionnaires were administered directly to professional on site. Different statistical tools were used for the analysis - measure of central tendency (mode), percentage score and mean item score. The data collected was processed and analysed using SPSS (Statistical Programme for Social Sciences version 20 ).

\section{Findings and Discussion}

\section{A. Introduction}

This section presents the data as obtained from the field as well as their analysis and the findings emanating from them. First, respondent's background and the area of business operation and appropriate annual turnover were highlighted and summarised. Thereafter, the results in terms of retention release, policy, commonest type and method, commonest amount are presented and discussed.

Table 1 shows the number of different stakeholders interviewed in this survey. From the table most of the respondents were Quantity Surveyors which is about $30 \%$ of the population of repondeents, $2 \%$ were structural engineers, $2 \%$ were project coordinator, $6 \%$ were project managers, $6 \%$ were project engineers, $2 \%$ were head of operations in their companies, $2 \%$ were financial manager for their company, $12 \%$ were site engineers/supervisors, $6 \%$ were director of the contracting firm, $8 \%$ were civil engineers, $\%$ were business development manager, $2 \%$ were architects and $20 \%$ of the respondent did not specify. 
Table 1: Job title of respondent

\begin{tabular}{lll}
\hline Titled & Frequency & Percent \\
\hline None & 10 & 20.0 \\
Architect & 1 & 2.0 \\
Business Development manager & 1 & 2.0 \\
Civil Engineer & 4 & 8.0 \\
Director & 3 & 6.0 \\
Engineer & 6 & 12.0 \\
Financial manager & 1 & 2.0 \\
Head of Operation & 1 & 2.0 \\
Project Engineer & 3 & 6.0 \\
Project Manager & 3 & 6.0 \\
Project coordinator & 1 & 2.0 \\
Quantity Surveyor & 15 & 30.0 \\
Structural Engineer & 1 & 2.0 \\
Total & 50 & 100.0 \\
\hline
\end{tabular}

Table 2: Years of experience in the construction industry in years

\begin{tabular}{lll}
\hline Years & Frequency & Percent \\
\hline $1-5$ & 12 & 24.0 \\
$6-10$ & 13 & 26.0 \\
$11-15$ & 10 & 20.0 \\
$16-20$ & 6 & 12.0 \\
$21-25$ & 5 & 10.0 \\
$26-30$ & 3 & 6.0 \\
Unspecified & 1 & 2.0 \\
Total & 50 & 100.0 \\
\hline
\end{tabular}

Table 3: Area of business operation in the construction industry: if a constructing firm

\begin{tabular}{lcccc}
\hline Area of business & Frequency & Percent & $\begin{array}{c}\text { Valid } \\
\text { Percent }\end{array}$ & $\begin{array}{c}\text { Cumulative } \\
\text { Percent }\end{array}$ \\
\hline $\begin{array}{l}\text { Building } \\
\text { construction only }\end{array}$ & 6 & 12.0 & 15.0 & 15.0 \\
$\begin{array}{l}\text { Civil engineering } \\
\text { construction only }\end{array}$ & 2 & 4.0 & 5.0 & 20.0 \\
$\begin{array}{l}\text { Building and civil } \\
\text { engineering }\end{array}$ & 31 & 62.0 & 77.5 & 97.5 \\
$\begin{array}{l}\text { construction only } \\
\begin{array}{l}\text { Others } \\
\text { Unspecified }\end{array}\end{array}$ & 1 & 2.0 & 2.5 & 100.0 \\
Total & 10 & 20.0 & & \\
\hline
\end{tabular}

Table 4: Specialist contracting

\begin{tabular}{lcccc}
\hline & Frequency & Percent & $\begin{array}{c}\text { Valid } \\
\text { Percent }\end{array}$ & $\begin{array}{c}\text { Cumulative } \\
\text { Percent }\end{array}$ \\
Electrical & 2 & 4.0 & 13.3 & 13.3 \\
Mechanical & 2 & 4.0 & 13.3 & 26.7 \\
Other & 8 & 16.0 & 53.3 & 80.0 \\
Electrical and & 3 & 6.0 & 20.0 & 100.0 \\
Mechanical & 35 & 70.0 & & \\
Unspecified & 50 & 100.0 & & \\
Total & & & \\
\hline
\end{tabular}

Table 5: Respondents from consultancy firm

\begin{tabular}{lcccc}
\hline & Frequency & Percent & $\begin{array}{c}\text { Valid } \\
\text { Percent }\end{array}$ & $\begin{array}{c}\text { Cumulative } \\
\text { Percent }\end{array}$ \\
\hline Architectural & 5 & 10.0 & 23.8 & 23.8 \\
Civil Engineering & 8 & 16.0 & 38.1 & 61.9 \\
$\begin{array}{l}\text { Quantity surveying } \\
\text { Mechanical and }\end{array}$ & 5 & 10.0 & 23.8 & 85.7 \\
$\begin{array}{l}\text { Electrical } \\
\text { Engineering }\end{array}$ & 2 & 4.0 & 9.5 & 95.2 \\
$\begin{array}{l}\text { Others } \\
\text { Unspecified }\end{array}$ & 1 & 2.0 & 4.8 & 100.0 \\
Total & 29 & 58.0 & & \\
\hline
\end{tabular}

Table 2 gives the number of years of respondent in the construction industry. The table shows that $24 \%$ have $1-5$ years of experience, $26 \%$ have 6-10years of experience, $20 \%$ have 11-15years of experience, 12 have 16-20years of experience, $10 \%$ have 21-25years of experience, and $6 \%$ have 26-30years of experience in the construction industry while $2 \%$ did not specify their years of experience. From the table, it can be seen that most respondents have $6-10$ years followed by 1 - 5years of experience and 11 - 15 years of experience. Therefore, this research work is quiet reliable.

Table 3 shows area of operation of respondent's in the construction industry. From the table, about $12 \%$ of respondent are into building construction only, $4 \%$ are into civil engineering only, $62 \%$ are into building and civil engineering construction, $2 \%$ are into other kinds of constructions while $20 \%$ did not specify their area of operations.

Table 4 shows the number of specialist contractors that responded to the questionnaire. The table shows that $4 \%$ were electrical contractors, $4 \%$ were mechanical contractor, and $6 \%$ were both mechanical and electrical contractors while $16 \%$ were into other type of specialist contracting.

Table 5 shows respondents from consulting firm. From the table, Civil Engineering has the highest frequency of 8 with the largest percent (16\%). However, both Architectural and Quantity Surveying have equal frequency of 5 each to score $10 \%$.

This Table 6 shows the approximate value of project the company has handled. Form the table about $22 \%$ have handled jobs below 100 million naira, $22 \%$ have handled jobs 
Table 6: The approximate annual turnover (value of project) of the company

\begin{tabular}{lcccc}
\hline & Frequency Percent & $\begin{array}{c}\text { Valid } \\
\text { Percent }\end{array}$ & $\begin{array}{c}\text { Cumulative } \\
\text { Percent }\end{array}$ \\
\hline Below N100 million & 11 & 22.0 & 23.9 & 23.9 \\
N100 - 500 million & 11 & 22.0 & 23.9 & 47.8 \\
N501 million - & 9 & 18.0 & 19.6 & 67.4 \\
1billion & 15 & 30.0 & 32.6 & 100.0 \\
Over N1 Billion & 4 & 8.0 & & \\
Unspecified & 50 & 100.0 & & \\
Total & & & & \\
\hline
\end{tabular}

Table 7: Duration of releases of retention on the projects handled

\begin{tabular}{|c|c|c|c|c|c|}
\hline $\begin{array}{l}\text { Retention } \\
\text { practices }\end{array}$ & $\begin{array}{l}\text { None of } \\
\text { projects }\end{array}$ & $\begin{array}{c}\text { Some } \\
\text { of the } \\
\text { project } \\
\text { s }\end{array}$ & $\begin{array}{c}\text { Most } \\
\text { of the } \\
\text { project } \\
\text { s }\end{array}$ & $\begin{array}{c}\text { All } \\
\text { project } \\
\text { s }\end{array}$ & $\begin{array}{c}\text { Mean } \\
\text { Score } \\
2.21\end{array}$ \\
\hline $\begin{array}{l}\text { Within six } \\
\text { months } \\
\text { after the } \\
\text { practical } \\
\text { completion } \\
\text { or } \\
\text { immediately } \\
\text { after the } \\
\text { defect } \\
\text { liability } \\
\text { period }\end{array}$ & 17 & 16 & 7 & 2 & 1.59 \\
\hline $\begin{array}{l}\text { Between six } \\
\text { and } 12 \\
\text { months } \\
\text { after } \\
\text { practical } \\
\text { completion }\end{array}$ & 28 & 7 & 6 & 4 & 1.55 \\
\hline $\begin{array}{l}\text { Between } 12 \\
\text { months and } \\
24 \text { months } \\
\text { after } \\
\text { practical } \\
\text { completion }\end{array}$ & 2 & 3 & 7 & 25 & 2.75 \\
\hline $\begin{array}{l}\text { Beyond } 24 \\
\text { months } \\
\text { after } \\
\text { practical } \\
\text { completion }\end{array}$ & 0 & 1 & 3 & 32 & 2.96 \\
\hline
\end{tabular}

Table 8: Retention policy of the client and contractor's willingness to tender for a project

\begin{tabular}{lcc}
\hline & Frequency & Percent \\
\hline Yes & 25 & 50.0 \\
No & 8 & 16.0 \\
Occasionally & 14 & 28.0 \\
Unspecified & 3 & 6.0 \\
Total & 50 & 100.0 \\
\hline
\end{tabular}

between 100-500 million naira, 18\% have handled jobs of between N501 millionN1billion and 30\% have handled jobs of over N1billion while $8 \%$ did not specify.

\section{B. Duration of Release of Retention in the Nigerian Construction Industry}

From table 7 the overall mean score (MS = 2.21) benchmarked the duration of release of retention on the projects handled by the respondents. It can be seen from the table that release of retention is usually delayed; release within six months after practical completion or immediately after DLP (MS = 1.59), between six and twelve months after practical completion (MS=1.55).

Majority of the respondents whose retention is eventually released either between 12 months and 24 months after practical completion (MS $=2.75$ ) or beyond 24 months (MS $=$ 2.96) after practical completion got it grossly belated. The delayed release of retention portends outright non-payment of due retention money.

Respondents were asked to indicate if the retention policy of the client determines the company's willingness to tender for project. From table 8, 50\% agreed it determines their willingness to tender for a project while $16 \%$ said it does not determine their willingness to tender for a project and $28 \%$ said it determines occasionally.

\section{Retainage Methods in Use in Nigerian Construction Industry}

Respondents were asked to indicate the methods common with different type of clients they have worked with. From the analysis of responses in table 9 it can be seen that most local government clients prefer percentage retention method, and also most state and federal government clients use percentage retention method. 
Table 9: The commonest type of retention method adopted by the client

\begin{tabular}{|c|c|c|c|c|c|c|c|c|c|c|}
\hline \multirow[b]{2}{*}{ Client } & \multicolumn{2}{|c|}{$\begin{array}{c}\text { Percentage } \\
\text { retention }\end{array}$} & \multicolumn{2}{|c|}{$\begin{array}{l}\text { Fixed amount } \\
\text { of retention }\end{array}$} & \multicolumn{2}{|c|}{$\begin{array}{c}\text { Bank } \\
\text { guarantee }\end{array}$} & \multicolumn{2}{|c|}{$\begin{array}{c}\begin{array}{c}\text { Insurance } \\
\text { bond }\end{array} \\
\end{array}$} & \multicolumn{2}{|c|}{ Project bank account } \\
\hline & frequency & $\%$ & Frequency & $\%$ & frequency & $\%$ & frequency & $\%$ & frequency & $\%$ \\
\hline Local government & 18 & 36 & 2 & 4 & 2 & 4 & 0 & 0 & 0 & 0 \\
\hline State government & 21 & 42 & 4 & 8 & 3 & 6 & 3 & 6 & 0 & 0 \\
\hline Federal government & 20 & 40 & 2 & 4 & 5 & 10 & 2 & 4 & 0 & 0 \\
\hline Int'l organisations & 13 & 26 & 1 & 2 & 7 & 14 & 4 & 8 & 0 & 0 \\
\hline Clubs and Associations & 16 & 32 & 1 & 2 & 5 & 10 & 2 & 8 & 0 & 0 \\
\hline Religious organisations & 17 & 34 & 3 & 6 & 2 & 4 & 4 & 8 & 0 & 0 \\
\hline Individual & 23 & 46 & 5 & 10 & 3 & 6 & 5 & 10 & 0 & 0 \\
\hline Manufacturing companies & 13 & 26 & 4 & 8 & 7 & 14 & 2 & 4 & 0 & 0 \\
\hline Financial Services companies & 12 & 24 & 3 & 6 & 7 & 14 & 5 & 10 & 0 & 0 \\
\hline General services \& merchandise companies & 15 & 30 & 5 & 10 & 4 & 8 & 2 & 4 & 0 & 0 \\
\hline Properties development companies & 20 & 40 & 7 & 14 & 5 & 10 & 6 & 12 & 0 & 0 \\
\hline
\end{tabular}

Table 10: The commonest amount of retention

\begin{tabular}{|c|c|c|c|c|c|c|c|c|}
\hline \multirow[b]{2}{*}{ Client } & \multicolumn{2}{|c|}{$\begin{array}{c}5 \% \text { of each progress } \\
\text { payment }\end{array}$} & \multicolumn{2}{|c|}{$\begin{array}{c}10 \% \text { of each } \\
\text { progress payment }\end{array}$} & \multicolumn{2}{|c|}{$\begin{array}{c}5 \% \text { of the total cost } \\
\text { of work }\end{array}$} & \multicolumn{2}{|c|}{$\begin{array}{l}10 \% \text { of the total cost of } \\
\text { work }\end{array}$} \\
\hline & frequency & $\%$ & Frequency & $\%$ & Frequency & $\%$ & Frequency & $\%$ \\
\hline Local government & 8 & 16 & 7 & 14 & 2 & 4 & 0 & 0 \\
\hline State government & 7 & 14 & 8 & 16 & 10 & 20 & 3 & 6 \\
\hline Federal government & 8 & 16 & 8 & 16 & 12 & 24 & 0 & 0 \\
\hline Int'l organisations & 12 & 24 & 3 & 6 & 6 & 12 & 1 & 2 \\
\hline Clubs and Associations & 10 & 20 & 5 & 10 & 2 & 4 & 1 & 2 \\
\hline Religious organisations & 10 & 20 & 5 & 10 & 8 & 16 & 1 & 2 \\
\hline Individual & 15 & 30 & 5 & 10 & 3 & 6 & 5 & 10 \\
\hline Manufacturing companies & 11 & 22 & 9 & 18 & 5 & 10 & 2 & 4 \\
\hline Financial Services companies & 9 & 18 & 7 & 14 & 5 & 10 & 3 & 6 \\
\hline $\begin{array}{l}\text { General services \& merchandise } \\
\text { companies }\end{array}$ & 11 & 22 & 4 & 8 & 6 & 12 & 2 & 4 \\
\hline Properties development companies & 13 & 26 & 7 & 14 & 10 & 20 & 2 & 4 \\
\hline
\end{tabular}

In essence, most of the different types of client prefer percentage retention, while a fewer percentage prefer the use of retention of a fixed percentage method and the use of bank guarantee and insurance bond and none of the clients use the method of project bank account. A large percentage of clients prefer percentage retention, bank guarantee comes next after that and fixed amount of retention is the third mostly used method while insurance bond comes forth with only a few percentage but none of the client using project bank account is in the Nigerian construction industry.

\section{Amount Mostly Retained In the Nigerian Construction Industry}

The table below shows the amount mostly retained by clients in the Nigerian Construction Industry, from table 10 it can be deduced that retention of $5 \%$ of each progress payment is mostly used, followed by $5 \%$ of the total cost of the work, while a fewer percentage of clients retain 10\% of each progress payment and a very few percentage retain $10 \%$ of the total cost of the work

From the analysis carried out, majority of the respondents had experienced delay release of retention money (Table 7). This result confirms $[13,14,28,30]$ that payment of retention monies in CI mostly suffered delay to outright non-payment. Also, retention 
policy of clients affects contractors' willingness to tender for construction works (Table 8). This result buttresses [5] and [28] that retainage practice is a problem.

Further results show that percentage retention on valuation of work done at each valuation is mostly used in the Nigerian Construction Industry, although other systems such as retention of fixed amount of money and the use of bank guarantee and insurance bond are also in use (Table 9). In addition, the most commonly retained is five percent $(5 \%)$ of each progress payment with a few percentages of clients retaining five percent of the total cost of the work and ten percent of each progress payment (Table 10).

Furthermore, the three tiers of government clients' retention on valuation charges are non-discriminatory of category of contractors. Ideally, one would expect that public clients charge lesser retention in other to cushion financial challenge of small-medium sized construction firms since they are the focal point that drive substantial amount of construction activities. In a way, this result contradicts the push for zero retention on valuation of construction work by Office of Program Policy and Government Accountability (OPPAGA - 2000).

\section{Conclusion and Recommendation}

In conclusion, either delay or outright nonpayment of retention monies on valuation will add to financial difficulty of small and medium sized construction firms. Also, the retention policy of government, applying five (5) percent flat on their project does not consider the financial capacity of small and medium sized construction firms.
Arising from the conclusions drawn from this study, it is hereby recommended that government clients should considered differential retention deduction of less than five (5) percentage in favour of small and medium firms as a measure to harness and build their capacity to grow gross domestic product in Nigeria.

\section{References}

[1] Nasser, A.H. "The Effect of Payment Delay on Construction Projects in Gaza Strip", Unpublished M.Sc. thesis, the Islamic University of Gaqa-Palestine, 2013.

[2] Joint Contract Tribunal (JCT 2016 Edition). Sweet \& Maxwell Ltd

[3] Bausman, D.C. "Retainage Practice in the Construction Industry", Foundation of the American Subcontractors Association Inc. Alexandra, Virgin, 2004.

[4] Raina, P. "An Examination of the Retention Practice in the New Zealand Construction Industry", Doctoral thesis, Auckland University of Technology, Department of Built Environment, School of Engineering, Auckland, NZ, 2015.

[5] Pye Tait Consulting "Retention in the Scottish Construction Industry", Royal House, 110 Station Parade, Harrogate, North Yorkshire, England, 2019.

[6] Gbandi, E.C. and Amisssah, G.A. "Financing Options for Small and Medium Enterprises (SMEs) in Nigeria", European Scientific Journal, vol. 10 , no. 1,2014 , pp. $328-340$.

[7] National Bureau of Statistics, "Nigerian Gross Domestic Product", National Bureau of Statistics, Quarter 4, 2017

[8] Aniekwu, N. "Government Role in Developing the Construction Industry in Nigeria", Nigerian Journal of Industrial and System Studies, vol. 2, no. 4, 2004, pp. 1 - 13.

[9] Tzortzopoulos, P., Kagioglou, M. and Treadaway, K. "A taxonomy for Construction Clients”, CIB 16579pdf, 2007, pp. $545-557$. 
[10] Drew, D.S., Lo, H.P. and Skitmore, R.M. "The Effect of Client and Type and Size of Construction Work on a Contractor's Bidding Strategy", Building and Environment, vol. 36, no. 3, 2001, pp. 393 - 406.

[11] Osokomaiya, O.A "Retainage Practice in Nigerian Construction Industry", BTech project dissertation, Department of Quantity Surveying, Bells University of Technology, Ota, 2014.

[12] "Retention Payments in the Construction Industry: A Consultation on the Practice of Cash Retention under Construction Contract", Department of Business, Energy and Investment Strategy, 2020.

[13] Mafimidiwo, B. and Iyagba, R. "Comparative Study of Problems Facing Small Building Contractors in Nigeria and South Africa", Journal of Emerging Trends in Economics \& Management Sciences, vol. 6, no. 2, 2015, pp. $101-109$.

[14] Odenigbo, O.G. "Causes and Effects of Delayed Payment on Construction Project Delivery", Master dissertation, Department of Building, University of Lagos, Nigeria, 2018.

[15] Deloitte Access Economics, "Analysis of Security of Payment Reform for the Building and Construction Industry", Prepared for the Queensland Department of Housing and Public Works, https//www.deloitte.com.au, 2016.

[16] Oladinrin, T.O., Ogunsemi, D.R and Aje, I.O. "Role of Construction Sector in Economic Growth: Empirical Evidence from Nigeria", Federal University of Yola Journal of the Environment, vol. 2, no. 1, 2012, pp. 50 60.

[17] Dakhil, A. "The Contribution of the Construction Industry to Economic Development in Libya", PhD thesis, Liverpool John Moores University, England, 2013.

[18] Kirombo, H.M. "Factors Affecting Implementation of Occupational Health and Safety Measures in the Construction Industry: The Case of Mombasa County, Kenya", University of Nairobi, Kenya, 2012.

[19] Lu, S., Sexton, M.G. and Abbot, C. "Key Characteristics of Small Construction Firms:
A UK Perspective", CIB W065/055 Commissions: Transformation through construction, 2007, pp. 1-10.

[20] Apanviciene, R. and Daugeliene, A. "New Classification of Construction Companies: Overhead Cost Aspects", Journal of Civil Engineering and Management, vol. 17, Issue 4, 2011, pp. 457 - 466

[21]Jagafa, K. "A Framework for Construction Business Recovery in Small and Medium Sized Privately Owned Companies", PhD Thesis submitted to School of the Built-Environment College of Science and Technology, the University of Salford, UK, 2016.

[22] Ugochuckwu, S.C. and Onyekwena T. "Participants of Indigenous Construction in Nigeria Public Sector Construction Projects and Their Challenges in Managing Working Capital", International Journal of Civil Engineering, Construction and Estate Management, vol. 1, no. 1, 2014, pp.1-21.

[23] Business, Energy, \& Industrial Strategy BEIS, "Retention Payment in the Construction Industry", Research Paper 17, 2017.

[24] Office of Program Policy and Government Accountability - (OPPAGA), "Inflexibility in Contracting and Retainage Practices Could Hurt Construction Industry", Report No. 0026, 2000

[25] Oke, A. "Benefits and Level of Using Retention Bond for Construction Projects in Nigeria", Int'l Journal of Architecture, Engineering and Construction, vol. 2, no. 2, 2013, pp. $98-$ 105.

[26] Oke, A., and Ogunmola, P. "Retention Bond and Performance of Construction Projects in Nigeria", Journal of Construction Project Management \& Information, vol. 4, no. 1, 2014, pp. $721-733$.

[27] Knauf, J. "Regulatory Impact Statement Relations in Construction Contract", Ministry of Business, Innovation and Employment, New Zealand, 2014.

[28] Amoa-Abban, K. and Essuman-Mensah, A.K. "The Retention Concept: The Impact 
on Contractors Performance", Int'l Journal of Advanced Engineering Research and Technology, vol. 5, no. 5, 2017, pp. $371-392$.

[29] Raghavan, V.S. and Karthik, K. "Problems Faced by Small Scale Contractors in India", International Research of Engineering and Technology, vol. 2, no. 2, 2015, pp. 105-107.

[30] Ogunde, A., Owolabi, D., Olusola, K.O., Tunji-Olayemi, P., Amusan, L., Joshua, O. and Akhigbe, A.O. "Factors Affecting the Competencies and Project Delivery of SmallSized Indigenous Construction Firms in Lagos, Nigeria", Covenant Journal of Research in the Built Environment, vol. 4, no. 1, 2016, pp. 18.

[31] Amusan, L.M., Ayo, C.K., Opeyemi, J. and Oluwatobi, A. "Managing Residential Building Project Retention Money Using Building Informatics Parameters", Int'l journal of applied engineering research, vol. 12, no. 23, 2017, pp. 13711 - 13717.

[32] Masterman, J.W.E. and Gameson, R.N. "Clients Characteristics and Needs in Relation to Their Selection of Building Procurement System", Chartered Institute of Building 12576. Pdf, 1995, pp. $79-87$.

[33] Haugbolle, K. and Boyd, D. "Clients and Users in Construction", CIB publication, no. 408, 2016.

[34] Popper, K. "The Logic of Scientific Discovery", Taylor and Francis, 2005.

[35] Fellows, R.F. and Lu, A.M.M. "Research Methods for Construction", John Wiley \& Sons, 1997.

[36] Clarke, A. and Dawson, R. "Evaluation Research: An Introduction to Principles, Methods and Practice", Sage, London, 1999. 